\title{
MODEL PENDEKATANA AGAMA DALAM PENGENTASAN KEMISKINAN DI MALUKU
}

\author{
H. P. Badrun
}

\begin{abstract}
ABSTRAK
Penelitian tentang Model Pendekatan Agama dalam Pengentasan Kemiskinan di Maluku bertujuan untuk mengetahui lembaga-lembaga keagamaan yang turut berkiprah melakukan upaya pengentasan kemiskinan. Hasil penelitian mengidentifikasi empat lembaga alternatif sebagai model pendekatan agama dalam pengentasan kemiskinan di daerah ini, masingmasing : (1) RINAMAKANA (Katolik) di Ambon (2) Yayasan Bala Keselamatan (Gereja Bala Keselamatan) di Ambon (3) KSM-BMT Citra Ummat (Islam) di Ambon; dan (4) Yayasan Al Ikhlas (Islam) di Masohi.
\end{abstract}

\section{PENDAHULUAN}

\section{A. Latar Belakang dan Masalah Penelitian}

Proses pembangunan di Indonesia hingga kini telah sampai pada tahapan pembangunan jangka panjang kedua (PJP II). Dalam rentang waktu lebih seperempat abad hampir semua dimensi kehidupan telah disentuh oleh program pembangunan, termasuk upaya peningkatan taraf dan kualitas hidup rakyat.

Salah satu persoalan penting dalam proses pembangunan yang dilaksanakan selama ini ialah jumlah penduduk miskin atau pra sejahtera yang masih relatif besar, diperkirakan mencapai $14 \%$ atau 25 jutajiwa.

Untuk mengatasinya pemerintah mengadakan beberapa program pengentasan kemiskinan yang diharapkan menjadi gerakan nasional yang tidak hanya bergantung pada inisiatif pemerintah, tetapi juga mengikutsertakan masyarakat.

Dalam praktek di lapangan programprogram pemerintah seperti antara lain : Inpres Daerah Tertinggal (IDT), TAKESRA, KUKESRA, merniliki beberapa persamaan dengan kegiatan pengentasan kemiskinan yang dilaksana- kan oleh dan dari masyarakat termasuk yang dilakukan oleh atau melalui lembaga keagamaan. Kegiatan-kegiatan tersebut merupakan model-model pengentasan kemiskinan yang langsung menyentuh golongan miskin.

Upaya mengenali model-model pengentasan kemiskinan yang dilakukan masyarakat sangatlah penting karena hal itu mencerminkan tanggungjawab masyarakat mengatasi masalah sosial yang dihadapi sesamnya. Selain itu dengan mengenali berbagai model pengentasan kemiskinan swadaya masyarakat diharapkan dapat diidentifikasi model-model alternatif yang dipandang lebih relevan dengan tuntutan perkembangan dan dinamika masyarakat. Untuk pengenalan itu diperlukan upaya sungguh-sungguh,' berencana, dan sistimatis melalui kegiatan penelitian seperti halnya penelitian yang dilaporkan ini. Penelitian beranjak pada permasalahan bagaimana lembagalembaga tersebut melakukan fungsi dan peranannya mengentaskan kemiskinan masyarakat, bagaimana bentuk organisasinya, apa dan bagaimana kegaitankegiatannya, serta seperti apa keterlibatan orang miskin di dalamnya. 
MODEL PENDEKATAN AGAMA

DALAM PENGENTASAN KEMISKINAN DI MALUKU

\section{B. Tujuan dan Kegunaan Hasil Penelitian}

Penelitian tentang Model Pendekatan Agama dalam Pengentasan Kemiskinan di Maluku bertujuan untuk mendeskripsikan dan menganalisis model-model pendekatan agama dalam pengentasan kemiskinan di daerah ini melalui lembagalembaga yang bergerak di bidang ekonomi yang berlandaskan ajaran-ajaran agama.

Hasil penelitian diharapkan berguna sebagai masukan kepada pihak-pihak yang memiliki tugas dan fungsi serta kegiatan yang sama, baik di kalangan lembaga keagamaan maupun pemerintah. Hasil penelitian diharapkan pula berguna sebagai salah satu mata rantai kesinambungan pengembangan ilmu pengetahuan.

\section{Ruang Lingkup dan Batasan Opera- sional}

Berbagai istilah dan/atau konsep yang digunakan dalam penelitian ini perlu diberi batasan ruang lingkup dan operasionalisasi yang relavan.

Model pendekatan agama diartikan sebagai contoh suatu keadaan atau kegiatan yang merupakan representasi dari misi keagamaan mengenai suatu bidang kehidupan.

Kemiskinan, menurut Suparlan, dapat didefenisikan sebagai suatu standard tingkat hidup yang rendah; yaitu adanya suatu tingkat kekurangan materi pada sejumlah atau segolongan orang dibandingkan dengan standard kehidupan yang umum berlaku dalam masyarakat yang bersangkutan.

Pengentasan kemiskinan diartikan sebagai upaya atau kegiatan yang dilakukan untuk meningkatkan penghasilan orang atau masyarakat yang kekurangan materi agar standar tingkat hidupnya bertambah dan kehidupannya dapat terangkat dari kungkungan kemiskinan. Upaya pengentasan kemiskinan yang diteliti disini ialah berbagai kegiatan yang dilakukan oleh lembaga yang bertujuan untuk meningkatkan penghasilan orang miskin yang dibina.

Lembaga yang dimaksudkan disini ialah lembaga yang bergerak dibidang ekonomi atau salah satu bidang usaha dan kegiatannya ialah bidang ekonomi yang keberadaannya dimotivasi oleh dan berlandaskan ajaran-ajaran agama. Secara operasional, lembaga-lembaga yang diteliti disini ialah lembaga yang memenuhi kriteria sebagai berikut : (1) memiliki bidang usaha dan kegiatan nyata dibidang ekonomi; (2) memiliki sumber daya yang dibutuhkan khususnya biaya untuk melakukan usaha dan kegiatannya; (3) menghasilkan produksi yang bernilai ekonomi serta memiliki konsumen utama dari golongan miskin dengan sistem pendistribusian konsumsi yang jelas; (4) membawa misi salah satu agama yang diakui keberadaannya di lokasi penelitian. Termasuk dalam kriteria ini, lembaga yang bergerak dalam jasa perantara keuangan (financial intermediation) yang menggunakan dana dari segolongan masyarakat dan kemudian meminjamkan kepada golongan lain, dalam hal ini, golongan miskin.

Aspek-aspek yang diteliti dari masing-masing lembaga meliputi : (1) Sejarah dan Struktur organisasi lembaga; (2) Sumber dana dan Fasilitas yang dimiliki; (3) Aktivitas lembaga; (4) Peranan Lembaga dalam Upaya Pengentasan Kemiskinan; (5) Prospek Perkembangan Lembaga.

Sesuai dengan kriteria yang ditentukan mengenai kelayakan lembaga yang diteliti, maka ada 4 (empat) lembaga yang diamati di daerah Maluku yang memenuhi kriteria untuk dianalisis lebih lanjut. Keempat lembaga yang dimaksud adalah (1) RINAMAKANA, dari kalangan ummat Katolik; (2) Yayasan Bala Keselamatan dari golongan Kristen Protestan, 
khususnya Gereja Bala Keselamatan Ambon; (3) KSM-BMT Citra Ummat dari golongan Islam di Ambon; dan (4) Yayasan Al-Ikhlas dari golongan Islam di Masohi.

\section{GAMBARAN UMUM TEMUAN PENELITIAN}

Penduduk daerah Maluku yang berjumlah 1.898.217 jiwa (menurut data tahun pertama Pelita VI), lebih $30 \%$ di antaranya atau tepatnya $30,38 \%$ tergolong miskin. Mereka tersebar pada 812 desa yang mendapat bantuan Inpres Desa Tertinggal (IDT) atau $53 \%$ dari jumlah desa dan kelurahan yang terdapat pada empat kabupaten dan satu kotamadya se Propinsi Maluku.

Upaya pengentasan rakyat dari kemiskinan menjadi prioritas pembangunan regional dan daerah di Maluku sejak PJP I dan semakin ditingkatkan lagi pada PJP II ini dengan penentuan saaran dan kebijaksanaan yang relevan melalui program yanj terfokus dan terkait jelas secara langsung dengan keadaan kehidupan rakyat miskin. Beberapa di antara program-program antara lain ialah pemberian dana bergulir Inpres Desa Tertinggal (IDT), latihan/pembinaan menabung kepada keluarga miskin melalui program TAKESRA (Tabungan Kelurga Sejahtera), dan pemberian pinjaman melalui KUKESRA (Kredit Usaha Keluarga Sejahtera). Sekalipun pelaksanaannya tidak sunyi dari kendala, terutama mengenai sikap dan pola hidup serta etos kerja masyarakat penerima bantuan, namun program-program tersebut memberikan andil yang berarti dalam upaya peningkatan taraf kesejahteraan hidup warga binaan. Khusus program IDT, mulai trhun 1997 semua desa dan kelurahan di daerah Maluku terdaftar sebagai penerima program bantuan tersebut.
Selain melalui jalur formal pemerintah, upaya pengentasan kemiskinan rakyat dilakuan pula oleh masyarakat itu sendiri melalui antara lain organisasi dan lembaga swadaya masyarakat, termasuk lembaga yang keberadaannya dimotivasi dan/atau didasarkan pada ajaran-ajaran agama.

Di daerah Maluku, tiga agama yang mempunyai panganut yang besar yakni Islam, Kristen Protestan, dan Katolik, dengan perbandingan : Islam 58,81\% Kristen Protestan 35,55 \% dan Katolik $5,15 \%$. Selebihnya, tidak sampai $1 \%$.

Penganut agama Hindu dan Budha yang pada umumnya adalah pendatang/transmigran adalah : Islam 43,37 \%; Kristen Protestan 51,17 \%, dan Katolik $5,31 \%$. Selebihnya, sebanyak $0,15 \%$ penganut agama Hindu dan Budha. Untuk daerah Kabupaten Maluku Tengah : Islam 68,24 \%; Kristen Protestan 29,03\%; dan Katolik 1,68 \%. Selebihnya, sebanyak $1,05 \%$ adalah penganut agama Hindu dan Budha.

Upaya pengentasan kemiskinan di kalangan umat beragama di daerah Maluku pada dasarnya telah dilakukan oleh tokoh/Pemuka agama masing-masing bersamaan dengan kehadiran agamaagama tersebut di daerah ini. Ada yang diprogramkan sebagai bagian dari kegiatan penyebaran agama bersangkutan dan ada pula yang diprogramkan sebagai bagian dari misi agama bersangkutan. Dalam realisasinya, selama kurun waktu kehadiran agama bersangkutan, upaya' pengentasan kemiskinan dikalangan umat berama lebih bersifat kegiatan sosialkaritatif atau amal yang pada umumnya kurang memberikan dorongan kemandirian bagi orang miskin yang dibantu.

Kalangan Gereka Protestan Maluku (GPM) yang merupakan organisasi gereja yang terbesar umatnya di antara 30 organisasi gereja Protestan se Propinsi Maluk, baru tahun 1996 memprogramkan 
MODEL PENDEKATAN AGAMA

DALAM PENGENTASAN KEMISKINAN DI MALUKU

kegiatan pembinaan sosial ekonomi sebagai bagian dari program pembinaan jemaatnya. Sebelumnya, gereja ini mencanangkan program pembinaan umat melalui tiga bidang yakni : (1) bidang Iman, (2) bidang Ilmu, dan (3) bidang Sosial Budaya (setelah tahun 1996, bidang Sosial Budaya diganti dengan bidang sosial ekonomi). Secara konsepsional kegiatan bidang ini (sosial ekonomi) ditangani secara organisatoris dan berjenjang, mulai dari tingkat Sinode, tingkat Klasis, dan sampai ke tingkat Majelis Jemaat. Realisasinya belum tampak kecuali di tingkat Klasis Ambon dimulai tahun 1997 dalam bentuk pilot proyek yang bernama Proyek TAPPER (Tahun Pengembangan Potensi Ekonomi Keluarga) yang secara operasional diwujudkan berupa simpan-pinjam dan pembinaan usaha kecil (kios dan penjual penjaja hasil pertanian).

Gereja Protestan lain yang memiliki kegiatan pembinaan bidang sosial ekonomi bagi jemaatnya ialah Gereja Bala Keselamatan Ambon dalam bentuk proyek yang diberi nama PROKESKA (singaktan dari Proyek Kesejahteraan Keluarga). Kegiatan operasionalnya dalam bentuk pemberian bantuan usaha kecil dan pengembangan usaha, juga dalam bentuk simpan piniam. Usaha ini telah berlangsung dua puluh tahun (sejak tahun 1977) dan telah memiliki keluarga binaan (yang sementara dibina sekarang ini) sebanyak 190 kepala keluarga terbesar di 14 desa dalam wilayah Kotamadya Ambon.

Pimpinan umat Katolik, kliususnya dalam wilayah Keuskupan Amboina, sejak tahun 1966 telah mencanangkan upaya pembinaan umatnya di bidang sosial ekonomi dengan pertama-tama mendirikan sebuah lembaga khusus yang diberi nama Lembaga Pengembangan Sosial Ekonomi (LPSE) Keuskupan Amboina, kemudian pada tahun 1976 berubah nama menjadi LPSE RINAMAKANA, dan selanjutnya pada tahun 1982 berubah status menjadi yayasan dan bernama Yayasan RINAMAKANA. Sebelum berstatus yayasan, aktivitas lembaga masih sebanding antara kegiatan sosial karitatif dengan kegiatan sosial ekonomi, namun setelah berstatus yayasan kegiatan-kegiatannya lebih dititik beratkan pada upaya pembinaan kehidupan sosial ekonomi masyarakat, terutama umat Katolik yang lemah ekonomi pada umumnya mempunyai mata pencaharian sebagai petani dan nelayan tradisional serta buruh kasar. Program pembinaan yang ditawakan meliputi tiga kegiatan, yakni : (1) Pembinaan Ekonomi Rumah Tangga, (2) Program Bina Anggaran, dan (3) Pembinaan Usaha Mandiri. Yang menonjol di antara tiga kegaitan ialah Program Bina Anggaran yang kegiatannya lebih bersifat pemberian jasa perantara keuangan (financial intermediation) dengan jumlah nasabah (akhir tahun 1996) sebanyak 2.166 orang dan jumlah tabungan sebanyak Rp 170.701.000,- . Nasabahnya meliputi hampir semua kegiatan ekonomi sektor non formal dalam bentuk usaha perorangan dan kelompok kecil tidak hanya terbatas bagi umat Katolik tetapi juga ada dari umat Islam dan umat Protestan.

Di kalangan umat Islam, sejak PJP I bermunculan berbagai lembaga sosial keagamaan lokal yang pada umumnya bergerak di bidang pendidikan, da'wah, dan sosial, di samping perwakilan organisasi Islam level nasional yang telah ada selama ini. Beberapa di antara lembaga dan organisasi tersebut juga memprogramkan kegiatan ekonomi, namun pada umumnya hanya terbatas dalam lingkungan warga lembaga dan/atau organisasi itu sendiri. Kegiatan bertujuan ganda yakni di satu pihak untuk memberikan bekal keterampilan bagi warganya atau 
anggotanya dan di lain pihak untuk memperoleh dana pembiayaan kegaitan dan pengembangan lembaga/organisasi bersangkutan. Upaya melibatkan masyarakat berpenghasilan rendah atau golongan miskin yang ada di sekitarnya tampaknya belum mendapat perhatian yang sungguh-sungguh.

Sebuah yayasan lokal bernama Yayasan Nurul Ikhlas yang didirikan tahun 1991 tetapi mengalami perkembangan yang cukup pesat, lebih memusatkan perhatian pada bidang pendidikan formal berupa madrasah Ibtidaiyah dan bidang sosial lainnya seperti mendirikan panti asuhan. Siswa madrasahnya cukup banyak (248 orang) sebagian berasal dari pulau Seram dan dari daerah pedalaman; 70 orang di antaranya tergolong anak kurang mampu atau anak orang miskin sehingga yayasan mendirikan panti asuhan untuk menampung mereka. Untuk memberikan bekal keterampilan kepada para santri, yayasan membuka usaha pertanian dan peternakan dengan bekerja sama Balai Latihan Kerja Departemen Tenaga Kerja Kotamadya Ambon, hasil usaha ini digunakan untuk biaya konsumsi dan lain-lain para santri asuhan panti serta biaya kegiatan intern lainnya.

Yayasan AlWathan, juga di Kotamadya Ambon, yang lebih dahulu didirikan tetapi mempunyai kegiatan yang sama dengan yayasan Nurul Ikhlas, juga mempunyai kegiatan ekonomi produktif seperti usaha peternakan dan pertukangan yang dikelola oleh dan hasilnya diperuntukkan bagi kalangan dalam yayasan sendiri.

Organi^asi Muhammadiyah di Ambon, mendirikan sebuah koperasi bernama Koperasi Amanah, bergerak dalam unit usaha pertckoan, namun anggotanya hanya terbatas di kalangan pegawai negeri, dan tidak menyentuh masyarakat golongan bawah yang lemah ekonomi.
Di Kota Masohi, ibukota Kabupaten Maluku Tengah, terdapat tidak kurang dari 10 lembaga/organisasi sosial keagamaan Islam, antara lain Mathlaul Anwar, Al Hidaya, Yayasan Ikhlas, Al Kutub, Jamiatul Muslim, serta perwakilan beberapa organisasi Islam level nasional seperti GUPPI, MDI, ICMI, MUI, dan BAZIS. Ternyata baru yayasan Al Ikhlas yang disamping mengelola kegiatan pendidikan dan da'wah juga mengelola bidang usaha ekonomi. Walaupun usaha yang dibina masih sangat sederhana yakni mempersewakan besak, namun sasarannya jelas yakni golongan ekonomi lemah dari masyarakat lingkungannya sehinga turut berperan aktif dalam upaya pengentasan kemiskinan masyarakat di sekitarnya.

Belakangan ini, ICMI pusat menawarkan kepada umat Islam Indonesia salah satu usaha ekonomi produktif yang potensial untuk menjangkau masyarakat golongan ekonomi lemah atau golongan miskin dalam bentuk dan nama Baitul Maal Wat Tamwil (disingkat BMT). Sampai pada pertengahan tahun 1997, telah terbentuk 12 unit BMT di daerah Maluku terdiri atas : 4 unit di kota Ambon, 6 unit di kota Masohi, dan 2 unit di Ternate; yang telah aktif beroperasi baru 4 unit yakni 2 unit di Ternate dan 2 unit di Kota Ambon, salah satu diantaranya ialah BMT Citra Ummat yang bergerak dalam kegiatan simpan pinjam. BMT Citra Ummat, dalam operasinya, menawarkan 7 (tujuh) macam simapanan dengan sistem bagi hasil (disebut Simpanan Mudharabah), yakni: Simpanan Mudharabah Idul Qurban, Simpanan Mudharabah Biasa, Simpanan Mudharabah Idul Fitri, dan Simpanan Mudharabah Haji dan Umrah. Dua yang terakhir yakni Simpanan Idul Fitri dan Simpanan Haji dan Umrah belum beroperasi, walaupun lembaganya sudah diresmikan. Sampai pertengahan tahun 1997, BMT 
Citra Ummat telah berhasil menghimpun dana dari nasabahya sejumlah Rp. 10.772.599 dan dana inilah yang dijadikan salah satu passiva dalam pengelolaan kegiatannya. Jenis kegiatan lain yang dilakukan BMT Citra Ummat ialah memberikan pinjaman usaha produktif bagi masyarakat ekonomi lemah namun memiliki potensi untuk berusaha mandiri. Ada 65 orang nasabah dengan bantuan yang diberikan sebanyak Rp. 11.626.000 (minimal Rp. 60.000,- maksimum Rp. 1.000 .000 ,- setiap nasabah) yang mengelola 8 jenis usaha kecil meliputi : penjuan sayur-sayuran di pasar, penjual di kios, penjual eceran bebas, tukang las, usaha parut kelapa di pasar, peternak ayam, penjual pakaian bekas, dan penjual tahu tempe.

\section{ANALISIS LEMBAGA ALTERNATIF}

A. RINAMAKANA

\section{Sejarah dan Struktur Organisasi Lembaga}

Pemikiran untuk meningkatkan kehidupan sosial ekonomi umat Katolik di wilayah Keuskupan Amboina terutama bagi mereka yang bekerja sebagai buruh, tani, dan nelayan yang pada umumnya tergolong lemah ekonomi, telah berkembang di kalangan tokoh-tokoh agama Katolik setempat sejak tahun 1950. Namun demikian pernikiran itu baru dapat diwujudkan pada tahun 1966 dengan djdirikannya Lembaga Pengembangan Sosial Ekonomi (LPES) Keusukupan Amboina.

Selama lima tahun pertama sejak kelahirannya, LPES Keuskupan Amboina tidak dapat berbuat banyak kecuali lebih memfokuskan perhatian pada penanganan kegiatan yang bersifat sosial-karikatif sesuai tuntunan kebutuhan mendesak dari sebagian besar ummat. Kemudian secara berangsur, tetapi dengan perencanaan yang matang, titik berat kegiatan dialihkan dari yang bersifat sosialkarakatif ke kegiatan yang bersifat sosial ekonomi. Program pembinaan kegiatan ekonomi ummat mulai ditangani secara intensif pada tahun 1982, setelah lembaga ini berubah status dan nama menjadi Yayasan RINAMAKAN.

Yayasan RINAMAKANA, sejak berstatus hukum sebagai yayasan, mempunyai perangkat organisasi yang terdiri dari Badan Pengurus dan Pelaksanaan Harian. Struktur dan personalia Badan Pengurus Yayasan yang pertama terdiri dari :

Ketua : Nyonya Wanda Latumahina Lopulisa

Sekretaris: : W.G. Tuju

Bendahara : Suster Francesco Meons PBHK

Anggota : E. Rettob Peter Chr. Melchers S.Y.

Dua orang personalia di atas yakni W.G. Tuju dan Suster Francesco Meons PBHK adalah anggota Kuratorium yang diunjuk Uskup Amboina selaku wakil seluruh masyarakat Katolik Maluku untuk memimpin pertama RINAMAKANA.

Pelaksana Harian Yayasan RINAMAKANA sekarang ini tersusun sebagai berikut :

Ketua : Suster Franceso Meons PBHK

Sekretaris: : Suster Lusiana Taberubun PBHK

Penghubung: Suster Emile Rumangun PBHK

Struktur organisasinya dilengkapai dengan bidang-bidang operasional meliputi : (1), Pendidikan dan Latihan (2) Massa Massa, (3) Kerumahtanggaan, (4) Bidang Anggaran, 
(5) Bantuan Sosial, (6) Adminstrasi Keuangan, dart (7) Usaha Pertanian dan Peternakan.

2. Sumber Dana dan Fasilitas yang dimiliki

Dana yang digunakan RINAMAKANA selama ini bersuber dari hasil usaha swadaya sendiri dan bantuan sponsor; yang bersumber dari hasil usaha swadaya sendiri meliputi antara lain: usaha peragenan media massa cetak dari Jakarta, usaha pertanian/ perkebunan dan peternakan, usaha penginapan, art shop (toko hasil karya seni klien), percetakan dan fotocopy. Yang bersumber dari bantuan sponsor antara lain dari Pemda Tk. I Maluku, Departemen Sosial, Pinjaman Bank, hasil kerjasama dengan berbagai yayasan dan LSM dalam dan Luar Negeri.

Fasilitas lain yang dimiliki antara lain sebuah gedung perkantoran permanen lengkap dengan peralatan yang lazim termasuk komputer dan mesim fotocopy, serta sebuah mobil operasional.

3. Aktiftas Lembaga

Yayasan RINAMAKANA didirikan dengan tujuan untuk melakukan pembangunan, pengembangan dan pembinaan masyarakat terutamam masyarakat golongan ekonomi lemah, khususnya di bidang sosial ekonomi. untuk mencapai tujuan itu yayasan secara tetap dan berkesinambungan melakukan dua kegiatan pokok yakni: a. Kegiatan Ekonomi, danb. Kegiatan Sosial. Kegiatan di bidan ekonomi, dalam pelaksanaannya dijabarkan menjadi tiga program pokok: yakni 1) Program Penbinaan Ekonomi Rumah Tangga, 2) Program Bina Anggran, dan 3)Program Pembinaan Usaha Mandiri. Sedang kegiatan di bidang sosial, meliputi tiga kegiatan yakni: 1) Bantuan sosial rutin; 2) Bantuan sosial
Yayasan Dharmais, dan 3) Bantuan sosial insidentil.

\section{a. Kegiatan Ekonomi}

1. Program Pembinaan Ekonomi Rumah Tangga

Tujuan utama dari program ini ialah terciptanya pengaturan ekonomi rumah tangga yang terbuka, bertanggung jawab dan mengacu ke masa depan. Program ini merupakan basis dari seluruh usaha pengembangan sosial ekonomi masyarakat yang ditangani RINAMAKANA. Bentuk usaha berupa: usaha bersama pembangunan rumah, koperasi konsumsi, tabungan mini, dan kredit mini. Program pembinaan ekonomi rumah tangga ini merupakan program awal dari kegiatan ekonomi yang dilakukan RINAMAKANA.

\section{Program Bina Anggran}

Program ini melatih orang atau klien binaan untuk belajar menabung secara terarah demi masa depan mereka. Proram Bina Anggaran yang dilaksanakan RINAMAKANAAA merupakan hasil kerjasama antara RINAMAKAN dengan Yayasan Purba Danarta Semarang yang pelaksanaanna dimulai pada tahun 1972. Program ini disambut dengan baik sekali oleh masyarakat Maluku, terbukti dari banyaknya anggota masyarakat yang mendaftarkan diri selaku nasabah/klien, tidak hanya terbatas dikalangan umat Katolik tetapi juga banyak dari umat agama lain, seperti Islam dan Kristen Protestan. Tahun pertama pelaksanaan program ini (1974) telah berkumpul tabungan dari klien sebanyak Rp. 1.888.265,dan tahun ke tiga (1976) telah terkumpul sebanyak Rp. 2.786.865,dari penabung sebanyak 542 orang. 
Akhir tahun 1995, jumlah tabungan mencapai Rp. 170.701.000,- berasal dari 2.166 orang penabung. Nampaknya program bina anggran dewasa ini, menempati leading position dalam keseluruhan program kegiatan ekonomi lembaga.

3. Prograni Pembinaan Usaha Mandiri Program ini bertujuan untuk membina anggota keluarga warga masyarkat lapisan bawah yang lemah ekonomi tetapi memiliki potensi untuk melakukan usaha perekonomian secara mandiri, terbuka, dan betanggung jawab.

Wujud nyata dari Program ini terdiri dari dua bentuk pelayanan: (1) Pinjaman Usaha Mandiri, dan (2) Pembinaan Usaha Kecil.

Pinjaman Usaha Mandiri diberikan dalam bentuk pinjaman kecil dengan persyaratan lunak; contoh : pinjaman minimal Rp $100.000,-$ per orang yang pengembaliannya dapat dilakukan dengan angsuran harian (maksimal 26 hari) dan/atau angsuran bulanan (maksimal 6 bulan) dengan bunga yang mengacu pada standar bunga Bank Pemerintah. Maksud utama pemberian pinjaman ialah agar nasabah/klien dapat membuka usaha kecil secara mandiri. Untuk mendorong pemupukan modal, para klien diwajibkan menyisihkan sejumlah tertentu uang, selain angsuran pinjaman, untuk ditabung di yayasan. Untuk memulai usahanya setiap klien diberikan latihan dan pendampingan. Hingga tahun 1996, jumlah anggota binaan (klien) mencapai 600 orang.

Mengenai Program Pembinaan Usaha Kecil, program ini diperuntukkan bagi anggota masyarakat yang telah memiliki atau mengelola usaha kecil dimaksudkan sebagai bantuan pengembangan usaha mereka. Namun disyaratkan bahwa penerima bantuan sebelumnya adalah peserta Program Bina Anggaran. Bantuan dana yang diberikan dapat mencapai jutaan rupiah perorang (sesuai hasil studi kelayakan) dan disertai dengan bimbingan dan pendampingan dari yayasan.

Adapun bidang-bidang usaha yang diberikan bantuan pinjaman meliputi : jaul-jualan hasil bumi; kios-kios jualan kebutuhan seharihari; kelompok usaha pertenunan; usaha peternakan (ayam, kelinci, babi, dan sapi); eklompok usaha industri kerajinan dan industri rumah tangga; usaha penjualan jam tangan (per orangan); usaha pembuatan obat-obatan; dan usaha perkebunan (sayur-sayuran dan buah-buahan.

b. Kegiatan Sosial Karitatif

Kegiatan sosial karitatif merupakan kegiatan dasar dan pertama ditangani yayasan, yakni dengan suka rela membantu anggota masyarakat yang hidupnya menderita seperti anak yatim piatu, orang tuajompo yang tak terurusi, parajanda yang kurang mampu, serta anggota masyarakat yang cacat. Karena itu, sekalipun titik berat kegiatan dewasa ini lebih bersifat kegiatan sosial ekonomi, namun demikian kegaitan sosial kartatif tetap diindahkan. Wujud kegiatan ini yang diprogramkan, meliputi tiga macam yakni : 1) Bantuan sosial rutin; 2) Bantuan Sosial Yayasan Dharmais; dan 3) Bantuan sosial lain yang bersifat insidentil).

Bantuan sosial rutin berupa pelatihan keterampilan, terutama bagi kaum ibu dan remaja, membantu dalam proses pernikahan bagi pasangan yang kesulitan dalam hal dana dan ketentuan 
adat; menyantuni para janda miskin, anak yatim, orang tua jompo, dan orangmiskin sekedar untuk menyambung hidup.

Bantuan sosial Yayasan Dharmais, dalam bentuk menyalurkan dana dan bertanggung jawab operasional pemberian bantuan Yayasan Dharmais Pusat Jakarta kepada anak yatim yang dipantikan, membantu orang-orang cacat, membantu pengobatan orang berpenyakit lepra, membantu ibu-ibu lemah ekonomi yang menanggung kehidupan satu keluarga, serta membantu ibu-ibu yang "bermasalah". Wujud bantuan yang diberikan berupa : uang tunai untuk keperluan : biaya sekolah bagi anak sekolah, biaya perawatan penyakit kusta, dan modal usaha (pinjaman tanpa bunga); ada pula bantuan berupa bahana makanan dan pakaian jadi. Untuk bantuan ini RINAMAKANA secara tetap mendapat dropping dana dari Yayasan Dharmais setiap tahun, dan untuk beberapa tahun terakhir rata-rata $\mathrm{Rp} 90.000 .000,-$ (sembilan puluh juta rupiah) per tahun.

Bantuan sosial lain, dimaksudkan ialah penyaluran dana bantuan dari beberapa lembaga sponsor, terutama dari luar negeri. Bantuan ini meliputi : (1) Bantuan Yayasan Rena dari negeri Belanda untuk menolong biaya operasi anak dan/atau orang sumbing. Kerjasama dengan lembaga sponsor dimulai sejak tahun 1991, dan sampai tahun 1994, RINAMAKANA telah menyalurkan bantuan kepada 55 orang anak sumbing dari daerah-daerah Ternate, Seram, Kei, Tanimbar, Ambon, dan Fak-Fak (Irian Jaya); (2) Bantuan Yayasan Liliane, juga dari negeri Belanda untuk anak-anak penderita cacat (terutama cacat musibah). Kerjasama dengan Yayasan Liliane dimulai sejak tahun 1994 dan hingga tahun 1996 telah dibantu sepuluh orang pasien terbanyak bantuan biaya pengobatan dan operasi di luar Maluku (Yogya, Jakarta, Surabaya, dan Ujungpandang).

\section{Peranan Lembaga dalam Upaya Pengentasan Kemiskinan}

Dua pokok kegiatan yang

dilaksanakan RINAMAKANA selama ini yakni Kegiatan Sosial Karitatif dan Kegiatan Ekonomi ditujukan kepada sasaran yang jelas yakni anggota atau kelompok masyarakat yang lemah ekonomi, mereka yang berada pada kondisi kehidupan marjinal, orang atau golongan miskin tanpa membedakan suku/etnis dan agama/kepercayaan yang dianut. Bantuan yang diberikan RINAMAKANA kepada mereka tidak sekedar untuk membantu mereka mengatasi kesulitan hidup sehari-hari, tetapi juga ditujukan untuk membantu mereka meringankan taraf hidup dengan merangsang, mendorong, dan mengembangkan potensi yang mereka miliki untuk pada gilirannya mampu berdiri sendiri.

Dari upaya pembinaan yang dilakukan RINAMAKANA maka ratusan dan bahkan ribuan klien yang dibina melalui berbagai kegiatan ekonomi tersebut berhasil dientaskan dari kehidupan miskin dan ketidakberdayaan ekonomi, sekedar menyebutkan bahwa ratusan rumah tangga tuna wisma setelah mereka dibantu maka berhasil mendirikan rumah sendiri di Ambon dan Masohi; ribuan orang lemah ekonomi dari berbagai jenis pekerjaan berhasil dibina menjadi penabung yang konsisten; ratusan pengusaha kecil yang bergerak di sektor non formal dapat dikembangkan 
usaha mereka dan sebagian di antara mereka dapat beralih ke sektor formal. Karena itu, dapat difahami kalau semua warga binaan yang mendapat bantuan merasa sangat tertolong, sehingga pada waktuwaktu tertentu berdatangan pernyataan mereka ke staf RINAMAKANA berupa ucapan terima kasih; bahkan ada di antara mereka yang sudah berhasil "menjadi orang" turut pula memberikan sumbangan untuk fonds yayasan.

5. Prospek Perkembangan Lembaga

Apa yang dicapai dan disumbangkan oleh RINAMAKANA selama ini sebagai kiprahnya terhadap kemanusiaan dan pembangunan merupakan hasil optimal yang dapat dilakukan sesuai dengan potensi yang dimiliki serta peluangpeluang yang dapat dimanfaatkan. Betapapun hasil yang dicapai karena dilandasi oleh iman dan didorong oleh motivasi keagamaan. RINAMAKANA menilainya sebagai karya pengabdian yang memiliki nilai lebih. Dengan pemahaman seperti ini RINAMAKANA telah membulatkan tekad untuk melanjutkan dan bahkan lebih meningkatkan kiprahnya sesuai dengan misi kehadirannya.

Tampaknya eksistensi dan prospek lembaga ini cukup meyakinkan karena antara lain, status yang jelas dan fasilitas yang dimiliki, dan sikap kemandirian yang ditonjolkan; selain itu kehadiran lembaga telah memperoleh respons proaktif dari masyarakat secara meluas, program-programnya yang diupayakan selalu sejalan dengan program pemerintah, serta memiliki jaringan-jaringan mitra kerja yang luas, dalam dan luar negeri.
Di balik itu, RINAMAKANA menyadari bahwa beberapa permasalahan yang selama ini cukup potensial untuk menjadi hambatan bila tidak dapat diantisipasi secara dini. Permasalahan lingkungan berupa antara lain kondisi geografis daerah Maluku yang terkenal dengan seribu pulau, keterbatasan prasarana dan sarana komunikasi, keterikatan sebagian masyarakat pada adatistiadat yang kaku, serta pola hidup masyarakat terutama di pedesaan yang cenderung konsumtif dan pasrah pada kondisi alam. Permasalahan kelembagaan berupa antara lain kurangnya tenaga pelaksana yang professional, keterbatasan dana, dan keterbatasan sarana penunjang. Namun demikian, pengelola RINAMAKANA memandang permasalahan-permasalahan itu sebagai tantangan yang harus dihadapi dan ditasi demi eksistensi dan kelanjutan misinya.

\section{B. YAYASAN BALA KESELAMATAN}

\section{Sejarah dan Struktur Organisasi Lembaga}

Yayasan Bala Keselamatan didirikan pada tahun 1972 dan memperoleh status hukum sebagai yayasan yang terdaftar dengan Nomor Akte Notaris No. 23 Tanggal 14 Desember 1972 dan terdaftar di Departemen Sosial R.I. dengan nomor pendaftaran No. 1745/KPTS/B B S/II/86 Tanggal 25 Pebruari 1986.

Yayasan Bala Keselamatan didirikan oleh Gereja Bala Keselamatan Ambon sebagai lembaga pelaksana misi sosial ekonomi gereja Bala Keselamatan. Secara operasional, aktivitas lembaga dilaksanakan oleh sebuah proyek yang diberi nama : Proyek Kesejahteraan Keluarga Anugrah 001 
Ambon" disingkat PROKESKA ANUGRAH 001 AMBON.

Dalam priode yang berlangsung sekarang, susunan pengurus proyek terdiri dari :

Pimpinan Proyek : Kapten Ny. Henny Duhu

Bendahara/Tata : Ny.Corry

Usaha Usmany

Social Woker (SW1): Kapten Ny.

(Petugas pengem- Henny Duhu bangan)

Social Woker (Sw2): Nn. Dona

Taihatu

Pembina Rohani : Ny. Henny

Toisuta

Struktur kepengurusan proyek agak fleksibel, disesuaikan dengan kondisi dan situasi lokal serta urgensinya.

2. Aktivitas Lembaga

Sesuai dengan namanya yakni

Proyek Program Kesejahteraan Keluarga, lembaga ini bertujuan untuk meningkatkan taraf hidup dan kesejahteraan keluarga binaan terutama penganut/umat Gereja Bala Keselamatan yang lemah ekonomi atau mengalami kemiskinan. Hal ini didasarkan pada pandrngan gereja bahwa Pengabaran Injil tanpa disertai perbaikan hidup dalam masyarakat akan menjadi pemberitaan yang kosong."

Wujud operasional dari upaya lembaga meningkatkan taraf kesejahteraan warga binaannya, berupa bantuan dana dan keperiuaan hidup lain sesuai kebutuhan setempat. Untuk PROKESKA ANUGRAH 001 Ambon, bantuan yang diberikan berupa bantuan kepada anak-anak dan/anak sekolah serta bantuan kepada keluarga.

Bantuan kepada anak-anak diwujudkan dalam bentuk :

(1) Bantuan uang sekolah atau SPP dan BP3;
(2) Pembelian pakaian seragama sekolah, sepatu, tas, buku, dan alat tulis-menulis;

(3) Pembelian biaya mengikuti kursuskursus seperti : kursus komputer, kursus mengetik, kursus Bahasa Inggeris, dan kursus ketermpilan menjahit;

(4) Bantuan kesehatan dan biaya pengobatan;

(5) Bantuan pemberian makanan tambahan di sekolah;

Bantuan kepada keluarga atau bantuan umum, diberikan dalam bentuk :

(1)Pengadaan Air Bersih-(PAM), pembangunan sumur dan W.C;

(2) Bantuan untuk merenovasi rumah;

(3) Bantuan modal usaha, berupa :

- usaha kios (jual-jualan di kios);

- usaha-usaha rumah tangga, termasuk usaha kerajinan jahitmenjahit, waning sederhana;

- usaha pertanian, terutama pertanian sayur-sayuran dan buahbuahan;

- usaha peternakan ayam dan babi;

- usaha transportasi teluk/perahu; dan

- usaha bantuan perbengkelan

Bantuan sosial kepada anak-anak dan anak sekolah, diberikan secara selektif setelah melalui pengamatan langsung mengenai keadaan latar belakang ekonomi orang tua.

Bantuan modal usaha keluarga diberikan setelah dilakukan studi pengamatan langsung terhadap potensi calon penerima bantuan. Bantuan yang diberikan merupakan pinjaman lunak yang harus dikembalikan sesuai kesepakatan dan dikembalikan tanpa bunga. Bagi klien yang berhasil mengembalikan uang pinjamannya dengan lancar dan tepat waktu, dapat dibantu lagi dengan volume bantuan 
yang lebih besar dari sebelumnya. Bagi klien yang pengembalian pinjamannya kurang/tidak lancar tanpa alasan yang dapat diterima oleh pengelola proyek, menghadapi kemungkinan tidak akan menerima lagi bantuan dari proyek. Namun, demikian, keterlambatan penyetoran yang disertai dengan alasan yang dapat dibenarkan oleh pengelola proyek, memiliki peluang untuk mendapat lagi bantuan bahkan disertai bimbingan dari staf proyek.

3. Peranan Lembaga dalam Upaya Pengentasan Kemiskinan

Kehadiran Proyek Program kesejahteraan Keluarga Anugrah 001 Ambon adalah dimaksudkan untuk menyantuni dan membantu orang atau anggota masyarakat, terutama warga gereja Bala Keselamatan sendiri meningkatkan taraf kehidupan sosial ekonomi mereka. Bantuan diberikan kepada warga yang menurut pertimbangan pengelola memenuhi kriteria yang antara lain disyaratkan lemah ekonom dan/atau dapat dikategorikan golongan miskin.

Selama tiga tahun terakhir, proyek menyalurkan bantuan cuma-cuma atau gratis kepada sejumlah 210 anak sekolah untuk berbagai keperluan yang ditentukan. Sedangkan bantuan modal usaha, telah diberikan kepada sejumlah 190 kepala keluarga ekonomi lemah tersebar pada 14 desa/kelurahan se Kotamadya Ambon. Tidak kurang dari Rp 30.000.000,- (tiga puluh juta rupiah) dana telah diedarkan kepada kepala keluarga untuk modal usaha, namun sampai pada batas akhir waktu perjanjian, hanya sekitar sepertiga klien yang mengembalikan secara lancar.

Sesuai hasil pemantauan pengelola, bantuan modal usaha banyak yang berhasil, dalam arti klien yang dibantu berhasil mengembangkan usahanya bahkan ada yang telah mampu mandiri serta dapat membantu rekan-rekannya yang lain. ${ }^{4}$

Seorang klien di Desa Passo (wilayah Kecamatan Teluk Ambon Baguala, Kodya Ambon) ketika pertama bermohon, tergolong orang miskin (menurut keadaan lingkungannya) namun setelah mengembangkan usahanya selama tiga tahun berhasil mendirikan sebuah rumah batu yang memadi menurut ukuran setempat. Sementara itu, beberapa orang klien yang berdatangan ke pengelola proyek untuk dibelikan peralatan kelengkapan rumah tangga berupa televisi, kulkas, setelah berhasil mengembangkan usahanya.

4. Prospek Perkembangan Lembaga

Misi sosial ekonomi yang diemban oleh Yayasan Bala Keselamatan yang secara operasional diprogramkan oleh proyek PORKESKA merupakan bagian dari misi keagamaan atau misi gereja. Karena itu eksistensinya sangat tergantung kebijaksanaan dan kreatifitas pimpinan gereja setempat. Inisiatif dan kreatifitas tidak dapat diharapkan muncul dari luar kepemimpinan gereja, karena hal itu sudah merupakan salah satu tugas pimpinan gereja. Kepengurusan lembaga masuk dalam struktur kepengurusan gereja.

Dana yang digunakan membantu dan menyantuni klien selama ini, khususnya bagi Yayasan Bala Keselamatan Ambon seluruhnya berasal dari sponsor yang pengadaannya dikoordinasikan pimpinan pusat Gereja Bala Keselamatan. Belum pernah memperoleh bantuan dana dari pemerintah dan memang yayasan belum pernah memintanya. Dari kalangan jemaat pun yayasan belum pernah memungut dana. 


\section{KSM - BMT CITRA UMMAT}

1. Sejarah dan Struktur Lembaga

KSM - BMT Citra Ummat (singkatan dari Kelompok Swadaya Masyaratan Baitul Mai Tamwil Citra Ummat) merupakan BMT pertama yang hadir di daerah Maluku, khususnya di kota Ambon. Pengurusnya ' dibentuk sejak awal tahun 1996, namun baru dapat beroperasi pada bulan April 1996 setelah memperoleh rekomendasi dari ICMI Orwil Maluku (No. 005/ICMI-MAL/IV/96) clan mendapat Sertifikat dari Pusat Inkubasi Bisnis Usaha Kecil (Pinbuk) Pusat (No. 2501001/Pinbuk/XI/96), sesuai prosedur dan mekanisme yang berlaku.

Di seluruh Propinsi Maluku, pada saat penelitian dilakukan, sudah terbentuk 12 buah lembaga serupa (BMT): 4 buah di kota Ambon, 6 buah di kota Masohi (ibukota Maluku Tengah), dan 2 buah di kota Ternate. Dari 12 buah BMT yang ada itu, baru 4 buah di antaranya yang sudah beroperasi: yakni 2 buah di kota Ambon masing-mising KSM - BMT Citra Ummat (bergerak dalam usaha simpanpinjam) dan KSM - BMT Al Taqwa (bergerak dalam usaha penjualan bahan kebutuhan pokok sehari-hari), serta 2 buah di Ternate masing-masing BMT Al Irsyad dan BMT Mitra Ummat. BMT lainnya ( 8 buah) masih dalam tahapan konsolidasi.

Susunan Kepengurusan KSM-BMT Citra Ummat mengacu kepada Anggaran Dasar dan Anggaran Rumah Tangga BMT, serta pedoman dari Pinbuk dan mendapat rekomendasi dari ICMI Orwil Maluku. Susunan selengkapnya adalah sebagai berikut:

a. Pelindung, terdiri atas tiga orang tokoh ummat/masyarakat setempat (kota Anbon);

b. Badan Pengurus, terdiri atas: Ketua,
Wakil Ketua, Sekretaris, dan dua orang anggota;

c. Badan Pelaksana atau Pengelola, terdiri atas: seorang Direktur, dua orang Kasir, seorang yang menangani bidang Pembinaan/Pemasaran/ Supervisi, dan seorang yang menangani bagian Hubungan Masyarakat.

Komposisi personalia kepengurusan pertama ini, pada umumnya terdiri atas pegawai negeri dan terbanyak dari instansi BPKP Maluku, menyusul dari Kanwil Departemen Pertanian dan Departemen Dikbud setempat.

2. Dana dan Fasilitas yang dimiliki

Modal awal ketika KSM - BMT Citra Ummat didirikan Rp.4.350.000,yang diperoleh dari 21 orang pendiri dengan jumlah bervariasi setiap orang, minimal Rp.50.000,- dan maksimal Rp. 1.000.000,- (satu juta rupiah); penyetorannya pun tidak bersamaan, sesuai kesempatan masing-masing, dengan tunai dan/atau angsuran dari dua sampai empat bulan. Setelah operasional, secara berangsur dana dapat dihimpun dari nasabah yang melakukan aktivitas simpan-pinjam dengan sistem mudharabah sehingga dalam waktu singkat dapat terhimpun dana sebanyak Rp. 10.772.550,-

Fasilitas perkantoran untuk sementara menyewa sebuah bangunan kecil di J1. Sultan Babullah Lorong Arumbai No. 1 Kelurahan Silale Kecamatan Nusaniwe dengan alat kelengkapan berupa sebuah meja administrasi, sebuah lemari kas, sebuah lemari berkas, satu pasang kursi tamu, dan satu unit mesin komputer.

3. Aktivitas Lembaga

Dalam masa lebih kurang satu tahun beroperasi, KSM-BMT Citra Ummat telah melakukan dua jenis kegiatan di bidang keuangan (jasa 
perantara keuangan) yakni simpan pinjam dan pembiayaan usaha produktif masyarakat kecil.

Usaha simpan-pinjam dilakukan dengan memobilisasi simpanan dari anggota dan/atau jamaah dalam bentuk dan sistem simpanan mudharabah yaitu simpanan yang mendapatkan laba dengan cara bagi hasil. Ada tujuh macam simpanan mudharabah yang ditawarkan kepada masyarakat, yakni: (1)Simpanan Mudharabah Pendidikan, diperuntukkan bagi siswa dan mahasiswa yang sementara aktif mengikuti pendidikan untuk memenuhi berbagai kebutuhan mengikuti pendidikan; penyetoran dapat dilakukan setiap hari kerja dengan setoran awal minimal Rp.2.500,- dan setoran selanjutnya minimal Rp. 1.000,-; simpanan dapat ditarik setiap waktu hari kerja dengan sal do minimal Rp.2.500,-; pesertanya baru dua orang dengan jumlah tabungan dan laba bagi hasil sebanyak Rp. 106.406,-

(2) Simpanan Mudharabah Biasa, diperuntukkan bagi umum, baik perorangan maupun kelompok, dengan setoran awal minimal Rp.5.000,- dan setoran berikuinya minimal Rp. 1.000,setiap kali menyetor. Penarikan simpanan dapat dilakukan setiap hari maksimal Rp.1.000.000,- Jenis simpanan ini dapat dijadikan jaminan pinjaman uang pada BMT. Peserta aktif pinjaman ini sebanyak 25 orang dengan total simpanan Rp.8.880.752,per orang minimal Rp.10.134,- dan maksimal Rp.2.250.000,-

(3) Simpanan Mudharabah Idul Fitri. Untuk persiapan menghadapi perayaan Idul Fitri. Penyetoran setiap hari minimal Rp.2.500,- sedangkan setoran awal minimal Rp. 10.000,- Penarikan simpanan hanya dapat dilakukan saat menjelang hari raya Idul Fitri dengan saldo minimal Rp.2.500,-
(4) Simpanan Mudharabah Idul Qurban, untuk persiapan menghadapi hari raya Idul Qurban, terutama untuk biaya membeli hewan qurban. Penyetoran awal minimal Rp.5.000,- dan setoran berikutnya minimal Rp.2.500,- dan dapat dilakukan per hari, per minggu, dan per bulan. Penarikan hanya dapat dilakukan paling lambat dua minggu menjelang hari raya Idul Adha. Pihak KSM - BMT Citra Ummat dapat pula mengusahakan hewan qurban bagi nasabah.

(5) Simpanan Mudharabah Walimah, untuk keperluan biaya pesta perkawinan diri sendiri dan/atau anggota keluarga. Penyetoran dapat dilakukan per hari minimal Rp. 1.000,- sedangkan setoran awal minimal Rp. 10.000,Penarikan simpanan hanya dapat dilakukan menjelang pelaksanaan acara perkawinan, dengan mendapat diskon untuk keperluan dekorasi kaligrafi maksimal $50 \%$ dari laba bagi hasil yang diperoleh. Penabung aktif baru dua orang dengan jumlah simpanan ditambah bagi hasil sebanyak Rp.191.338,-

(6) Simpanan Mudharabah Haji dan Umrah, untuk biaya keperluan menunaikan ibadah haji dan umrah. Penyetoran awal minimal Rp.25.000,- dan penyetoran berikutnya minimal Rp. 10.000,- baik perorangan maupun kelompok. Penarikan simpanan hanya dapat dilakukan pada saat menjelang pendaftaran calon jemaah haji.

(7) Simpanan Mudharabah Pedagang, diperuntukkan bagi pedagang atau anggota masyarakat yang berminat untuk membuka usaha dan/atau mengembangkan usaha. Penyetoran awal minimal Rp.5.000,- dan setoran berikutnya minimal Rp.500,- dan dapat dilakukan setiap hari. Jenis simpanan ini dikaitkan dengan perolehan kredit 
dari BMT sehingga setoran dilakukan bersamaan dengan setoran angsuran pinjaman dari BMT. Hingga kini, jumlah penabung sebanyak 66 orang dengan jumlah tabungan keseluruhan sebanyak Rp. 1.493.300,-

Dari tujuh jenis Simpanan Mudharabah yang ditawarkan di atas, dua di antaranya belum ada peminatnya, masing-masing; Simpanan Mudharabah Idul Fithri dan Simpanan Mudharabah Haji dan Umrah. Jumlah dana yang terhimpun lewat lima jenis Simpanan Mudharabah sebanyak Rp. 10.772.500,- dan dana inilah yang dijadikan salah satu passiva dalam pengelolaan KSM- BMT Citra Ummat.

Jenis kegiatan lain yang dilaksanakan BMT Citra Ummat ialah kegiatan pembiayaan usaha produktif bagi masyarakat kecil yang sangat membutuhkannya. Kelancaran pelaksanaan kegiatan ini sangat tergantung pada kete "sediaan dana yang dapat dihimpun oleh lembaga, baik yang berasal dari pendiri, peminjam, dan laba yang diperoleh. Hingga pertengahan tahun 1997 jumlah pengusaha kecil yang mendapat bantuan kredit sebanyak 65 orang dengan total bantuan yang diberikan sebanyak Rp.11.626.000,- Besarnya bantuan yang diberikan kepada setiap pengusaha minimal Rp.60.000,- dan maksimal Rp.1.000.000,- dengan jangka waktu pengembalian minimal 30 hari dan maksimal 180 hari.

Adapun jenis-jenis usaha kecil produktif yang memperoleh bantuan BMT Citra Ummat selama ini ialah:

(1) Penjual sayur-sayuran di dalam pasar (ierutama empat pasar besar di Ambon, dalam wilayah Kecamatan Nusaniwe yakni Pasar Rumah Tiga, Pasar Kakap, Pasar Mardika, dan Pasar Wayame);
(2) Penjual barang campuran yang memiliki kios dan lods di pasar;

(3) Penjual beras;

(4) Tukang las dan pembuat alat-alat dapur dari kaleng;

(5) Usaha parut kelapa di dalam pasar;

(6) Peternak dan penjual ayam potong dan petelur;

(7) Penjual pakaian bekas; dan

(8) Penjual tahu dan tempe.

4. Peranan Lembaga dalam Upaya Pengentasan Kemiskinan

Keberadaan KSM - BMT Citra Ummat dalam fungsi utamanya selaku pelayanan jasa perantara keuangan, walaupun masih dalam usianya seumur jagung, sedikit-banyak telah turut memacu percepatan kegiatan dan pertumbuhan potensi ekonomi umat, terutama mereka yang tergolong ekonomi lemah yang selama ini hanya mampu bergerak di sektor non formal. Dengan demikian kehadiran lembaga ini telah turut membawa perubahanperubahan positif dalam kehidupan sosial-ekonomi umat. Golongan ekonomi lemah dan/atau orang miskin yang mendapat bantuan kredit dari BMT Citra Ummat, sedikit-banyak telah merasakan perubahan-perubahan positif seperti antara lain:

- meningkatnya penghasilan keluarga/rumah tangga;

- secara psikologis para nasabah tidak lagi dihantui oleh hutang sebagaimana halnya pinjaman dari rentenir yang memang banyak berkeliaran di tengah-tengah masyarakat; keadaan demikian mendorong mereka untuk lebih bergairah melakukan kegiatan usaha;

- bantuan yang diterima dari BMT Citra Ummat dapat menumbuhkan kemandirian bagi orang miskin yang menerimanya, sehingga pada gilirannya tumbuh kesadaran diri untuk 
merubah kehidupan, dalam arti meningkatkan taraf hidup mereka, terangkat dari kungkungan kemiskinan;

- pengembalian kredit dari bantuan yang diterima berfungsi ganda yakni di samping pengembalian kredit itu sendiri juga sekaligus nasabah mempunyai simpanan yang setelah jangka waktu pengembalian kredit berakhir dapat diambil dan digunakan untuk keperluan lain seperti biaya pendidikan anak-anak dan peningkatan usaha.

5. Prospek Perkembangan Lembaga

KSM - BMT Citra Ummat, sebagai lembaga pelayanan jasa perantara keuangan (financial intermediation) memiliki prospek yang cukup cerah, karena adanya faktor-faktor pendukung, berupa antara lain :

- Aktivitas keuangan yang dilakukan KSM - BMT Citra Ummat dikelola dengan prinsip-prinsip perbankan, sementara masyarakat secara meluas telah mengenal dan mengambil manfaat jasa perbankan;

- Sistem pengelolaannya, di samping mengacu kepada prinsip-prinsip perbankan pada umumnya juga secara khusus di dasarkan pada ajaran-ajaran Islam antara lain mengenai tuntutan saling tolong-menolong dan membantu pihak yang lemah, tuntutan keadilan, kebersamaan, dan lain-lain;

- Memiliki sumber daya manusia (pengelola) yang cukup dapat diandalkan karena antara lain memiliki profesionalisme yang relevan, aktif dan kreatif dengan latar belakang usia yang rata-rata masih muda (paling tua usia 30 tahun) serta pendidikan yang memadai (SLTA dan Sarjana);

- Sistem operasionalnya sangat sederhana antara lain dengan sistem bagi hasil yang rendah dan relatif seimbang, prosedur pengurusan yang relatif mudah dan tidak berbelit-belit;

- Sasaran utama ditujukan kepada golongan miskin dan ekonomi lemah yang merupakan bagian terbesar dari anggota masyarakat di lokasi penelitian.

Selain faktor pendukung, tidak dapat disangkal adanya kendala atau hambatan, berupa antara lain:

- animo masyarakat untuk memanfaatkan lembaga ini cukup tinggi namun ketersediaan dana masih sangat terbatas;

- sikap dan pola hidup masyarakat golongan ekonomi lemah yang masih banyak terikat dengan adat-istiadat yang kaku serta pola hidup yang konsumtif;

- belum adanya hubungan koordinasi yang baik dengan lembaga-lembaga keagamaan konvensional yang relevan seperti BAZIS dan instansi/ pejabat formal agama Islam setempat, seperti instansi/pejabat Departemen Agama, pimpinan pesantren dan/atau lembaga pendidikan agama;

- fasilitas penunjang secara fisik masih terbatas.

Namun demikian, pihak pengelola menyadari bahwa hambatanhambatan itu dirasakan adanya karena usia lembaga yang relatif masih sangat mudah serta pengalaman pengelola yang masih berkurang. Karena itu'halhal yang dianggap hambatan itu diposisikan sebagai tantangan yang harus dihadapi dan diatasi dengan serangkaian tindakan-tindakan antisipatif.

\section{YAYASAN AL IKHLAS DI MASOH1}

1. Sejarah dan Struktur Organisasi

Yayasan Al Ikhlas adalah salah satu dari sepuluh lembaga yang bersifat keagamaan di Kecamatan Amahai Kabupaten Maluku Tengah namun meru- 
pakan satu-satunya lembaga yang di samping bergerak di bidang pendidikan dan sosial, juga membina usaha yang bersifat ekonomi di wilayah kecamatan ini. Lembaga ini diresmikan berdirinya pada tanggal 21 Juli 1994 dan akte pendiriannya dikeluarkan tanggal 11 Maret 1995.

Inisiatif mendirikan yayasan Al Ikhlas ini dilatarbelakangi oleh pemikiran di kalangan tokoh-tokoh agama setempat mengenai perlunya lembaga sosial keagamaan menaruh perhatian terhadap upaya peningkatan taraf hidup masyarakat ekonomi lemah yang justru merupakan bagian terbanyak dari umat Islam setempat. Nama Al Ikhlas diambil dari nama masjid tempat berkumpulnya tokoh-tokoh agama setempat yang merumuskan inisiatif tersebut.

Struktur organisasinya dapat diketahui melalui susunan pengurus yang terdiri atas: Pelindung/Penasehat, Badan Pengurus itu yang dilengkapi dengan tujuh Seksi atau BiJang di antaranya terdapat Seksi Sosial/Kemasyarakatan dan Seksi Dana/Ekonomi.

Pelindung/Penasehat terdiri atas enam orang tokoh Islam setempat sedangkan Badan Pengurus terdiri atas unsur Ketua, unsur Sekretaris, dan unsur Bendaiiara, yang seluruhnya berjumlah 9 orang. Seksi atau Bidang ada tujuh dengan pengurus masing-masing bervariasi jumlahnya, dari yang paling sedikit (3 orang) yakni Seksi Hubungan Masyarakat sampai yang terbanyak (13 orang) yakni Seksi Dana/Ekonomi.

2. Dana dan Fasilitas yang dimiliki

Sebagai yayasan yang pada tahapan awal kegiatannya lebih bersifat sosial maka dana pembiayaan kegiatan banyak tergantung pada uluran tangan dermawan muslim sekitarnya bantuan dari pemerintah, bantuan dari dana BAZIS, dan sumbangan lain yang halal dan tidak mengikat. Selain itu dana juga dapat diperoleh lewat iuran santri Taman Pengajian Alquran dan dari hasil usaha bidang jasa yang dikelola.

Fasilitas lain yang dimiliki ialah gedung pusat kegiatan lengkap dengan alat perkantoran sederhana, di samping ruangan tempat belajar santri TPA.

\section{Aktivitas Lembaga}

Sesuai dengan fungsi lembaga yakni bergerak di bidang dakwah, pendidikan, dan ekonomi maka aktivitas lembaga diprogramkan dalam rangka pelaksanaan fungsinya itu.

a. Fungsi dakwah

Fungsi lembaga di bidang dakwah untuk sementara masih di orientasikan kepada dakwah lisan yang aplikasinya meliputi :

(1) memberikan ceramah agama dan pengajian di masjid dan tempattempat lain sesuai kebutuhan;

(2) memberikan bimbingan dan penyuluhan di bidang hukum dan kesehatan lingkungan, bekerjasama dengan instansi terkait.

b. Fungsi Pendidikan

Fungsi lembaga di bidang pendidikan, untuk sementara masih terbatas pada Taman Pengajian Alquran (TPA) yang santrinya cukup banyak sehingga dibuatkan ruangan/lokasi tersendiri lengkap dengan peralatannya. TPA ini secara organisasi dipertanggungjawabkan oleh Seksi Pendidikan dan secara operasional dipimpin oleh seorang kepala sekolah dan dibantu oleh seorang sekretaris/tata usaha dan seorang bendahara serta sejumlah tenaga pengajar.

c. Fungsi sosial-ekonomi

Fungsi sosial ekonomi lembaga untuk sementara baru diaplikasikan pada usaha penyewaan dan/atau sewabeli becak. Usaha ini tampaknya cukup prospektif karena peminat atau calon nasabah di lokasi cukup banyak. Becak merupakan kendaraan angkutan lokal yang banyak digunakan di lokasi.

Becak pertama dibeli yayasan pada bulan Januari 1997 dengan modal patungan beberapa orang anggota pengurus. Pada bulan Agustus 1997 , ketika dilakukan penelitian, jumlah becak yang dioperasikan sudah mencapai 11 buah.

Sistem penyewaan dilakukan dengan dua cara sewa biasa, maka nasabah atau tukang becak harus 
merubah kehidupan, dalam arti meningkatkan taraf hidup mereka, terangkat dari kungkungan kemiskinan;

- pengembalian kredit dari bantuan yang diterima berfungsi ganda yakni di samping pengembalian kredit itu sendiri juga sekaligus nasabah mempunyai simpanan yang setelah jangka waktu pengembalian kredit berakhir dapat diambil dan digunakan untuk keperluan lain seperti biaya pendidikan anak-anak dan peningkatan usaha.

5. Prospek Perkembangan Lembaga

KSM - BMT Citra Ummat, sebagai lembaga pelayanan jasa perantara keuangan (financial intermediation) memiliki prospek yang cukup cerah, karena adanya faktor-faktor pendukung, berupa antara lain :

- Aktivitas keuangan yang dilakukan KSM - BMT Citra Ummat dikelola dengan prinsip-prinsip perbankan, sementara masyarakat secara meluas telah mengenal dan mengambil manfaat jasa perbankan;

- Sistem pengelolaannya, di samping mengacu kepada prinsip-prinsip perbankan pada umumnya juga secara khusus di dasarkan pada ajaran-ajaran Islam antara lain mengenai tuntutan saling tolong-menolong dan membantu pihak yang lemah, tuntutan keadilan, kebersamaan, dan lain-lain;

- Memiliki sumber daya manusia (pengelola) yang cukup dapat diandalkan karena antara lain memiliki profesionalisme yang relevan, aktif dan kreatif dengan latar belakang usia yang rata-rata masih muda (paling tua usia 30 tahun) serta pendidikan yang memadai (SLTA dan Sarjana);

- Sistem operasionalnya sangat sederhana antara lain dengan sistem bagi hasil yang rendah dan relatif seimbang, prosedur pengurusan yang relatif mudah dan tidak berbelit-belit;

- Sasaran utama ditujukan kepada golongan miskin dan ekonomi lemah yang merupakan bagian terbesar dari anggota masyarakat di lokasi penelitian.

Selain faktor pendukung, tidak dapat disangkal adanya kendala atau hambatan, berupa antara lain:

- animo masyarakat untuk memanfaatkan lembaga ini cukup tinggi namun ketersediaan dana masih sangat terbatas;

- sikap dan pola hidup masyarakat golongan ekonomi lemah yang masih banyak terikat dengan adat-istiadat yang kaku serta pola hidup yang konsumtif;

- belum adanya hubungan koordinasi yang baik dengan lembaga-lembaga keagamaan konvensional yang relevan seperti BAZIS dan instansi/ pejabat formal agama Islam setempat, seperti instansi/pejabat Departemen Agama, pimpinan pesantren dan/atau lembaga pendidikan agama;

- fasilitas penunjang secara fisik masih terbatas.

Namun demikian, pihak pengelola menyadari bahwa hambatanhambatan itu dirasakan adanya karena usia lembaga yang relatif masih sangat mudah serta pengalaman pengelola yang masih berkurang. Karena itu halhal yang dianggap hambatan itu diposisikan sebagai tantangan yang harus dihadapi dan diatasi dengan serangkaian tindakan-tindakan antisipatif.

D. YAYASAN AL IKHLAS DI MASOHI

1. Sejarah dan Struktur Organisasi

Yayasan Al Ikhlas adalah salah satu dari sepuluh lembaga yang bersifat keagaman di Kecamatan Amahai Kabupaten Maluku Tengah namun meru- 
pakan satu-satunya lembaga yang di samping bergerak di bidang pendidikan dan sosial, juga membina usaha yang bersifat ekonomi di wilayah kecamatan ini. Lembaga ini diresmikan berdirinya pada tanggal 21 Juli 1994 dan akte pendiriannya dikeluarkan tanggal 11 Maret 1995.

Inisiatif mendirikan yayasan $\mathrm{Al}$ Ikhlas ini dilatarbelakangi oleh pemikiran di kalangan tokoh-tokoh agama setempat mengenai perlunya lembaga sosial keagamaan menaruh perhatian terhadap upaya peningkatan taraf hidup masyarakat ekonomi lemah yang justru merupakan bagian terbanyak dari umat Islam setempat. Nama Al Ikhlas diambil dari nama masjid tempat berkumpulnya tokoh-tokoh agama setempat yang merumuskan inisiatif tersebut.

Struktur organisasinya dapat diketahui melalui susunan pengurus yang terdiri atas: Pelindung/Penasehat, Badan Pengurus itu yang dilengkapi dengan tujuh Seksi atau Bidang di antaranya terdapat Seksi Sosial/Kemasyarakatan dan Seksi Dana/Ekonomi.

Pelindung/Penasehat terdiri atas enam orang tokoh Islam setempat sedangkan Badan Pengurus terdiri atas unsur Ketua, unsur Sekretaris, dan unsur Bendahara, yang seluruhnya berjumlah 9 orang. Seksi atau Bidang ada tujuh dengan pengurus masing-masing bervariasi jumlahnya, dari yang paling sedikit (3 orang) yakni Seksi Hubungan Masyarakat sampai yang terbanyak (13 orang) yakni Seksi Dana/Ekonomi.

2. Dana dan Fasilitas yang dimiliki

Sebagai yayasan yang pada tahapan awal kegiatannya lebih bersifat sosial maka dana pembiayaan kegiatan banyak tergantung pada uluran tangan dermawan muslim sekitarnya bantuan dari pemerintah, bantuan dari dana BAZIS, dan sumbangan lain yang halal dan tidak mengikat. Selain itu dana juga dapat diperoleh lewat iuran santri Taman Pengajian Alquran dan dari hasil usaha bidang jasa yang dikelola.

Fasilitas lain yang dimiliki ialah gedung pusat kegiatan lengkap dengan alat perkantoran sederhana, di samping ruangan tempat belajar santri TPA.

\section{Aktivitas Lembaga}

Sesuai dengan fungsi lembaga yakni bergerak di bidang dakwah, pendidikan, dan ekonomi maka aktivitas lembaga diprogramkan dalam rangka pelaksanaan fungsinya itu.

a. Fungsi dakwah

Fungsi lembaga di bidang dakwah untuk sementara masih di orientasikan kepada dakwah lisan yang aplikasinya meliputi :

(1) memberikan ceramah agama dan pengajian di masjid dan tempattempat lain sesuai kebutuhan;

(2) memberikan bimbingan dan penyuluhan di bidang hukum dan kesehatan lingkungan, bekerjasama dengan instansi terkait.

b. Fungsi Pendidikan

Fungsi lembaga di bidang pendidikan, untuk sementara masih terbatas pada Taman Pengajian Alquran (TPA) yang santrinya cukup banyak sehingga dibuatkan ruangan/lokasi tersendiri lengkap dengan peralatannya. TPA ini secara organisasi dipertanggungjawabkan oleh Seksi Pendidikan dan secara operasional dipimpin oleh seorang kepala sekolah dan dibantu oleh seorang sekretaris/tata usaha dan seorang bendahara serta sejumlah tenaga pengajar.

c. Fungsi sosial-ekonomi

Fungsi sosial ekonomi lembaga untuk sementara baru diaplikasikan pada usaha penyewaan dan/atau sewabeli becak. Usaha ini tampaknya cukup prospektif karena peminat atau calon nasabah di lokasi cukup banyak. Becak merupakan kendaraan angkutan lokal yang banyak digunakan di lokasi.

Becak pertama dibeli yayasan pada bulan Januari 1997 dengan modal patungan beberapa orang anggota pengurus. Pada bulan Agustus 1997, ketika dilakukan penelitian, jumlah becak yang dioperasikan sudah mencapai 11 buah.

Sistem penyewaan dilakukan dengan dua cara sewa biasa, maka nasabah atau tukang becak harus 
menyetor sewa harian sebanyak Rp.3.000,- setiap hari pakai, tanpa dibebani biaya perbaikan kerusakan kecil. Bila dengan cara sewa-beli nasabah juga diharuskan menyetor Rp.3.000,- setiap hari selama satu tahun. Setelah cukup satu tahun, penyewa dapat memiliki langsung becak yang disewanya itu. Rupanya cara tersebut pertama di atas yang banyak ditempuh karena pada umumnya penyewa bukan tukang becak profesional dan tidak ingin menjadi penarik becak tetap.

Prosedur penentuan pemakai sewa becak sesungguhnya pada kriteria tertentu, antara lain: penduduk resmi setempat, tergolong ekonomi lemah atau miskin, dan tidak memiliki sumber mata pencaharian tertentu; dan diutamakan yang ada anaknya yang menjadi santri di TPA Al Ikhlas.

Ditambahkan bahwa harga becak per buah di lokasi Rp.450.000,- sedangka penghasilan tukang becak per hari yang lazim rata-rata Rp. 10.000,-

Sewa becak perhari, baik sewa biasa maupun sewa beli yang berjumlah Rp.3.000,- itu, oleh pengelola yayasan, diadministrasikan untuk dua kebutuhan; pertama, untuk pemeliharaan becak (sewa bias;:) atau pengembalian harga becak (sewa beli) sebanyak Rp.2.000,-; kedua, untuk menutupi perhitungan biaya SPP bagi santri yang dibebaskan dari pembayaran karena ketidakmampuan orangtuanya.

Fungsi sosial ekonomi lain yang kini sementara dalam penjajakan oleh yayasan Al Ikhlas ialah merencanakan mendirikan/membentuk koperasi, apakah simpan-pinjam atau konsumsi. Bahkan ada beberapa orang anggota pengurus yayasan turut menjadi anggota pengurus dari Baitul Maal Wat Tamwil (BMT) yang sementara dalam persiapan pengoperasiannya di Masohi.

4. Peranan Lembaga dan prospeksi dalam upaya pengentasan kemiskinan

Kehadiran yayasan Al Ikhlas, di samping untuk melakukan kegiatankegiatan pembinaan kehidupan ekonomi untuk meningkatkan taraf kesejahteraan umat. Wujud kegiatan nyata yang pada tahap awal dapat dilakukan yakni sewa dan sewa-beli becak dirasakan sangat menolong masyarakat tertentu untuk memberikan lapangan pekerjaan sekaligus meningkatkan taraf kehidupan ekonomi mereka yang pada umumnya tergolong ekonomi lemah atau orang miskin.

Memperhatikan peminat yang cukup banyak yang ditandai dengan banyaknya permohonan yang masuk maka diperkirakan usaha ini memiliki prospek yang cerah dimasa-masa yang akan datang. Kendala yang dirasakan dewasa ini ialah keterbatasan modal dasar yang selama ini hanya diperoleh dari kesediaan sejumlah anggota pengurus untuk secara patungan mengusahakan pengadaan becak. Namun demikian bila setoran sewa tetap berjalan lancar seperti yang berjalan selama ini, maka ada optimisme yang beralasan bahwa kendala itu akan dapat diatasi, dan bahkan usaha dapat dikembangkan sesuai rencana yayasan.

\section{PENUTUP}

\section{A. Kesimpulan}

1. Upaya pengentasan rakyat dari kemiskinan di daerah Maluku, tidak hanya ditangani oleh pemerintah tetapi juga dilakukan oleh masyarakat sendiri, terutama melalui lembaga-lembaga sosial-ekonomi, termasuk lembaga yang keberadaannya dimotivasi dan berdasarkan ajaran-ajaran agama.

2. Kegiatan sosial-ekonomi yang dilakukan oleh lembaga-lembaga sosial keagamaan di daerah Maluku, termasuk di Kotamadya Ambon dan Kabupaten Maluku Tengah pada umumnya ditujukan untuk kepentingan intern lembaga sosial keagamaan bersangkutan, baik untuk kebutuhan warga sendiri maupun untuk keperluan pembiayaan kegaitan lembaga. Keberadaan lembaga-lembaga relevan yang telah turut berperan dalam upaya mengentaskan masyarakat sekitar dari kungkungan kemiskinan, masih sangat kurang; yang dapat diidentifikasi yakni: Yayasan 
RINAMAKANA dari kalangan umat Katholik; Proyek TAPPEK (Tahun Pengembangan Potensi Ekonomi Keluarga) dari Gereja Protestan Maluku (GPM) dan PROKESKA (Proyek Kesejahteraan Keluarga) dari Gereja Bala Keselamatan Ambon, keduanya dari umat Kristen Protestan; BMT (Baitul Maal Wat Tamwil) dan Yayasan Al Ikhlas dari umat Islam.

3. Kegiatan ekonomi yang ditangani lembaga-lembaga tersebut di atas pada umum-nya bersifat pemberian jasa perantara keuangan (financial intermediation): simpan-pinjam dan bantuan modal usaha, dan masih sangat kurang yang menangani kegiatan ekonomi yang memproduksi barang.

4. Perkembangan lembaga-lembaga ekonomi umat tersebut di daerah Maluku memiliki prospek yang cerah mengingat bentukbentuk kegiatan yang dilakukan sejalan dengan kegiatan sama yang dilakukan pemerintah namun mudah pengurusannya, dan sasaran utamanya ialah lapisan bawah dari strata ekonomi masyarakat.

\section{CATATAN}

BAB III

1) Perkataan/Istilah RINAMAKANA merupakan gabungan dari dua kata yang diambil dari bahasa daerah Maluku Tengah yakni RINA dan MAKANA. RINA berarti terang atau cahaya, dan MAKANA berarti kuat bersinar. Dengan demikian RINAMAKANA berarti cahaya yang bersinar/memancar dengan terang dan kuat (hasil wawancara H.P Badrun dengan Suster Emile Rumangun PBHK, salah seorang pengurus harian RINAMAKANA; tanggal 16 Agustus 1997 di kantornya)

2) Bapak Anton Solo, "Yayasan RINAMAKANA dan sejarah perkembangannya sejak 1966 - 1990". Makalah, disajikan pada Rapat Univikasi Karya Propinsi K.PBHK se Indonesia di Ambon yang berlangsung tanggal 18 s.d 29 Desember 1990, halaman 13.

3) Wawancara H.P.Badrun dengan pendeta Kapten Imanuel Duhu, Kepala Gereja Bala
Keselamatan Ambon, tanggal 13 Agustus 1997 di kantornya.

4) Wawancara H.P.Badrun dengan Kapten Ny. Henny Duhu, pemimpin proyek PROKESKA ANUGRAH 001 AMBON, tanggal 13 Agustus 1997 di kantornya.

\section{KEPUSTAKAAN}

Koentjaraningrat (Ed.)

1984 Masyarakat Desa di Indonesia, Jakarta Lembaga Penerbit Fakultas Ekonomi Universitas Indonesia.

1988 Manusia dan Kebudayaan di Indonesia, Jakarta Jembatan; cetakan XII.

Pemda Propinsi Daerah Tingkat I Maluku

1994 Rencana Pembangunan Lima Tahun Keenam Daerah Propinsi Daerah Tingkat I Maluku 1994/1995 - 1998/1999. Buku $\mathrm{V}$ (Pembangunan Daerah Tingkat II se Propinsi Maluku)

Robert Cohmbers

1996 Memahami Desa Secara Partisipatif (terjemahan). Yogyakarta, Kanisius.

Rusli, Said, dkk. (Ed.)

$1995 \begin{aligned} & \text { Metodologi Identifikasi Go- } \\ & \text { longan dan Daerah Miskin } \\ & \text { Suatu Tinjauan dan Alternatif, }\end{aligned}$ Jakarta. Grasindo.

Wijaya, A.W. (Ed.)

Manusia Indonesia Individu
Keluarga dan Masyarakat,
Jakarta, Akademika Pressindo,
Edisi I.

